\title{
TINJAUAN FAKTOR-FAKTOR YANG MEMPENGARUHI WAKTU TUNGGU PELAYANAN REKAM MEDIS DI PENDAFTARAN RAWAT JALAN RSUD X KABUPATEN BANDUNG
}

\author{
Herlin Tiana', Lindya Mega Inka E ${ }^{2}$, Syaikhul Wahab ${ }^{3}$ \\ Politeknik Piksi Ganesha, Indonesia ${ }^{1,2,3}$ \\ herlintianaherlin@gmail.com ${ }^{1}$, lindyamega22@gmail.com², \\ syaikhulwahab@gmail.com ${ }^{3}$
}

Received: 03-08-2021

Revised : $15-10-2021$

Accepted: 18-10-2021

\begin{abstract}
Abstrak
Latar Belakang: Rumah sakit mempunyai misi memberikan pelayanan kesehatan yang bermutu dan terjangkau oleh masyarakat dalam meningkatkan derajat kesehatan manusia. Salah satunya waktu tunggu pelayanan rekam medis di pendaftaran rawat jalan. Rumah sakit harus menyediakan pelayanan rawat jalan yang mudah dan cepat diakses oleh pasien. Hal ini berpengaruh pada utilitas pasien terhadap citra pelayanan rumah sakit tersebut.
\end{abstract}

Tujuan: Tujuan dari penelitian ini adalah untuk menyelidiki tentang apa saja faktor-faktor yang dapat mempengaruhi waktu tunggu pelayanan rekam medis di pendaftaran rawat jalan RSUD X Kabupaten Bandung.

Metode: Metode penelitian yang digunakan adalah deskriptif. Cara pengumpulan data menggunakan pedoman observasi, wawancara dan kuesioner. Populasi penelitian ini adalah pasien yang datang ke tempat pendaftaran rawat jalan dan petugas rekam medis rawat jalan. Sampel dalam penelitian ini terbagi menjadi dua jenis yaitu pasien rawat jalan yang terdiri dari pasien baru dan pasien lama. Teknik pengambilan sampel yaitu purposive sampling.

Hasil: Dari hasil penelitian yang di dapat bahwa faktor yang mempengaruhi waktu tunggu pelayanan rekam medis di pendaftaran rawat jalan RSUD X Kabupaten Bandung meliputi; Penyimpanan, Sumber daya manusia yaitu data riwayat pendidikan petugas dan pada sumber daya material yaitu bahan, peralatan, dan fasilitas. Diperoleh rata-rata waktu tunggu untuk pasien baru yaitu 4 menit 11 detik dan rata-rata waktu tunggu pasien lama yaitu 6 menit 35 detik

Kesimpulan : Berdasarkan hasil tinjauan bahwa waktu tunggu pelayanan rekam medis di pendaftaran rawat jalan rumah sakit tersebut sudah dikategorikan singkat sehingga tidak ada permasalahan yang menonjol hanya saja pada faktor petugas yang tidak pernah mengikuti pelatihan rekam medis , tetapi tidak menutup kemungkinan karena faktor tersebut dapat menghambat waktu tunggu pelayanan rekam medis dan fasilitas tempat penyimpanan yang memiliki penerangan dan ventilasi yang kurang baik.

Kata kunci: rekam medis, waktu tunggu, rawat jalan. 


\begin{abstract}
Background: The hospital has a mission to provide quality and affordable health services to the community in improving human health status. One of them is the waiting time for medical record services at outpatient registration. Hospitals must provide outpatient services that are easily and quickly accessible to patients. This affects the utility of patients to the image of hospital services.

Objective: The purpose of this study was to determine the factors that can affect the waiting time for medical record services at the outpatient registration section of RSUD X Bandung Regency.

Methods: The research method used is descriptive. How to collect data using observation, interview guidelines and kuesioner. The population of this study were patients who came to outpatient registration and outpatient medical record officers. The sample in this study was divided into two types, namely outpatients consisting of new patients and old patients. The sampling technique is purposive sampling. Results: From the results of the study, it is known that the factors that affect the waiting time for medical record services at the outpatient registration of RSUD X Bandung Regency, among others; Storage, human resources, namely data on the education history of officers and material resources, namely materials, equipment, and facilities. The average waiting time for new patients is 4 minutes 11 seconds and the average waiting time for old patients is 6 minutes 35 seconds.
\end{abstract}

Conclusion: Based on the results of the review that the waiting time for medical record services at hospital outpatient registration has been categorized as short, so there are no prominent problems, only officers who have never attended medical record training, but do not rule out this possibility because these factors can hinder waiting time medical record services and storage facilities that have poor lighting and ventilation.

Keywords: medical record, waiting time, outpatient.

*Correspondent Author : Herlin Tiana

Email : herlintianaherlin@gmail.com

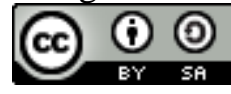

\title{
PENDAHULUAN
}

Rumah Sakit merupakan sarana kesehatan yang menyelenggarakan pelayanan kesehatan perorangan meliputi pelayanan promotif, preventif, kuratif dan rehabilitatif yang menyediakan pelayanan rawat inap, rawat jalan dan gawat darurat (RI, 2008). Fungsi Rumah Sakit itu sendiri adalah tempat menyelenggarakan pelayanan medik, pelayanan penunjang, pelayanan keperawatan, pelayanan rehabilitasi, dan pelayanan pencegahan 
penyakit. Kegiatan rumah sakit mencakup pelaksanaan pelayanan kesehatan dan pelaksanaan administrasi, pemeliharaan gedung, peralatan dan perlengkapan (Hidayat, 2017). Menurut (No, 44 C.E.), tentang membuat, melaksanakan, dan menjaga standar mutu pelayanan kesehatan Rumah Sakit sebagai acuan dalam melayani pasien.

Menurut Permenkes No.269/MENKES/PER/III/2008 rekam medis adalah berkas yang berisi catatan dokumen antara lain identitas pasien, hasil pemeriksaan, pengobatan yang telah diberikan, serta tindakan dan pelayanan lain yang telah diberikan kepada pasien. Tujuan rekam medis adalah menunjang tercapainya tertib administrasi dalam peningkatan pelayanan kesehatan di rumah sakit. Tertib administrasi merupakan salah satu faktor yang menentukan di dalam upaya pelayanan kesehatan di rumah sakit. Tanpa adanya suatu sistem pengelolaan rekam medis yang baik dan benar, maka tidak akan tercipta tertib administrasi rumah sakit sebagaimana diharapkan (Permenkes, 2008).

Menurut Keputusan Menteri Kesehatan RI nomor 1165/MENKES/SK/2007/bab 1, pasal 1 ayat 4 pelayanan rawat jalan adalah pelayanan pasien untuk observasi, diagnosis, pengobatan, rehabilitasi medik dan pelayanan kesehatan lainnya tanpa menginap di Rumah Sakit. Pemberian pelayanan di Instalasi Rawat Jalan pertama kali dilakukan TPP (Tempat Pendaftaran Pasien), yang dikelola oleh bagian rekam medis rawat jalan (Depkes, 1997).

Dimensi mutu pelayanan kesehatan adalah akses terhadap pelayanan yang ditandai dengan waktu tunggu pasien (Febriyanti et al., 2013). Waktu tunggu pasien dalam hal ini terhadap pelayanan rekam medis di pendaftaran rawat jalan merupakan salah satu hal penting yang akan menentukan citra awal pelayanan rumah sakit (Fuanasari et al., 2014). Waktu tunggu pasien merupakan salah satu komponen yang potensial menyebabkan ketidakpuasan. Waktu tunggu adalah waktu tunggu yang digunakan oleh pasien untuk mendapatkan pelayanan rawat jalan dan rawat inap dari tempat pendaftaran sampai masuk ke ruang pemeriksaan dokter (Karuniawati et al., 2016).

Pelayanan Rekam Medis yang baik dan bermutu tercermin dari pelayanan yang ramah, cepat serta nyaman (Ismawati et al., 2021). Pelayanan rekam medis rawat jalan dimulai dari tempat pendaftaran pasien sampai memperoleh dokumen rekam medis yang akan digunakan untuk mendapatkan pelayanan kesehatan. Berdasarkan standar penyediaan dokumen rekam medis pelayanan rawat jalan adalah 10 menit dan pelayanan dokumen rawat inap selama 15 menit (Depkes, 2007).

Peneliti memilih RSUD X Kabupaten Bandung berdasarkan kondisi-kondisi tertentu di masa pandemi saat ini. Peneliti sebelumnya telah mengajukan penelitian di Dinas Kesehatan untuk melakukan pengambilan data penelitian di puskesmas, akan tetapi Dinas Kesehatan tidak menyetujui hal tersebut dengan alasan bahwa Kota Bandung sedang mengalami lonjakan kasus Covid-19, sehingga peneliti mencari kembali rumah sakit yang memungkinkan untuk dilakukan pengambilan data penelitian.

Berdasarkan hasil survei awal di loket Rekam Medis pendaftaran Rawat Jalan Rumah sakit X Kabupaten Bandung didapatkan tempat pendaftaran pada rumah sakit ini terletak sebelah kiri dari gerbang masuk Rumah Sakit. Ruang pendaftaran tersebut terdapat 4 loket Pendaftaran Rawat Jalan yang terdiri dari, loket 1 melayani pasien umum dan loket 2,3,4 melayani pasien BPJS. pada loket pendaftaran buka pada hari senin-sabtu pukul 08.00-11.00. Pasien yang datang setiap harinya 30 orang. Pada loket TPPRJ ini sudah menggunakan sistem komputerisasi dalam menginput data pasien sehingga memudahkan untuk petugas pendaftaran dan pasien pun tidak menunggu terlalu lama. Pada loket TPPRJ terdapat lubang komunikasi, ada lubang bicara dan adanya penyekat atau pembatas pada loket. Sehingga petugas dalam melayani pasien secara langsung tidak menyebabkan petugas tertular penyakit atau virus . Loket TPPRJ juga luas dan bersih sehingga petugas merasa nyaman dalam melayani pasien. Ukuran meja di loket pendaftaran tidak terlalu tinggi hal tersebut memudahkan petugas dalam melayani pasien.

Adapun tujuan peneliti memilih topik ini untuk menyelidiki tentang apa saja faktor-faktor yang dapat mempengaruhi waktu tunggu pelayanan rekam medis di pendaftaran rawat jalan dan memberikan solusi. 
Berdasarkan latar belakang tersebut peneliti memilih topik penelitian dengan judul "Tinjauan Faktor-Faktor Yang Mempengaruhi Waktu Tunggu Pelayanan Rekam Medis Di Pendaftaran Rawat Jalan Di Rumah sakit X Kabupaten Bandung".

\section{METODE PENELITIAN}

Metode penelitian yang digunakan adalah deskriptif (Soendari, 2012). Lokasi penelitian di bagian Pendaftaran Rekam Medis Rawat Jalan Rumah Sakit X Kabupaten Bandung yang dilakukan pada bulan Juli sampai dengan bulan Agustus 2021. Populasi penelitian ini adalah pasien yang datang ke tempat pendaftaran Rawat Jalan Rumah sakit X Kabupaten Bandung berjumlah 30 orang dan seluruh staf Rekam medis berjumlah 13 orang dan 4 orang staf di bagian pendaftaran Rawat Jalan. Sampel dalam penelitian ini terbagi dalam dua jenis yaitu pasien rawat jalan yang terdiri dari pasien baru dan lama berjumlah 30 orang, staf atau petugas rekam medis rawat jalan Rumah Sakit X Kabupaten Bandung berjumlah 13 orang dan 3 orang di bagian pendaftaran rawat jalan. Pengumpulan data dilakukan wawancara, observasi dan kuesioner. Analisis data dalam penelitian ini menggunakan deskriptif.

\section{HASIL DAN PEMBAHASAN}

\section{A. Hasil Penelitian}

Table 1. Hasil perhitungan terhadap Rata-rata Waktu Tunggu Pelayanan dalam Tiap Tahapan Untuk Pasien Baru dan Pasien Lama di Bagian Rekam Medis Pendaftaran Rawat Jalan Rumah Sakit X Kabupaten Bandung Tahun 2021

\begin{tabular}{lcc}
\hline \multicolumn{1}{c}{ Tahapan } & Pasien Baru & Pasien Lama \\
\hline Waktu tunggu di Tempat Penerimaan Pasien & 1 menit 20 detik & 3 menit 25 detik \\
\hline Penyerahan KIB & - & 2 menit 28 detik \\
\hline Menulis ke dalam buku register & - & - \\
\hline $\begin{array}{l}\text { Membuat KIB pasien baru dan mengisi identitas } \\
\text { pasien baru }\end{array}$ & 2 menit 51 detik & - \\
\hline Waktu tunggu pencarian rekam medis pasien lama & - & 52 detik \\
\hline \multicolumn{1}{c}{ Total waktu } & 4 menit 11 detik & 6 menit 35 detik \\
\hline
\end{tabular}

Berdasarkan tabel 1 di atas, dari masing-masing tahapan untuk kedua jenis pasien didapatkan rata-rata terhadap keseluruhan waktu tunggu seperti pada tabel diatas. Berdasarkan tabel diatas diketahui bahwa rata-rata waktu tunggu untuk pasien baru secara keseluruhan adalah 4 menit 11 detik sedangkan rata-rata waktu tunggu untuk pasien lama secara keseluruhan adalah 6 menit 35 detik.

\section{Sumber Daya Manusia}

Jumlah petugas rawat jalan Rumah Sakit X Kabupaten Bandung adalah 3 orang dengan menggunakan alat bantu kuesioner. Jenis kelamin perempuan petugas rekam medis pendaftaran rawat jalan ada 3 orang. Umur petugas medis rawat jalan ada yang 26 tahun, 28 tahun, dan ada yang 29 tahun. Tingkat pendidikan petugas rekam medis rawat jalan 3 orang perguruan tinggi (Sarjana). Masa kerja di rekam medis rawat jalan ada yang 1 bulan, 2 tahun dan 4 tahun. Yang tidak pernah mengikuti pelatihan tentang rekam medis 3 orang. 
Tabel 2. Hasil pengukuran Terhadap Faktor SDM di Instalasi Rekam Medis Rawat Jalan Rumah Sakit X Kabupaten Bandung tahun 2021.

\begin{tabular}{ll}
\hline Faktor yang diukur & Jumlah \\
\hline Jenis Kelamin & - \\
\hline Laki-laki & 3 \\
\hline Perempuan & \\
\hline Umur & 1 \\
\hline 26 tahun & 1 \\
\hline 28 tahun sc & 1 \\
\hline 29 tahun & \\
\hline Pendidikan Terakhir & 0 \\
\hline SLTA/SMA & 0 \\
\hline Diploma & 3 \\
\hline Perguruan Tinggi (Sarjana) & \\
\hline Masa Kerja & 1 \\
\hline 1 bulan & 1 \\
\hline 2 tahun & 1 \\
\hline 4 tahun
\end{tabular}

Berdasarkan tabel 2 di atas, dari hasil pengukuran terhadap faktor SDM di Instalasi Rekam Medis rawat jalan. Dari tahapan petugas rekam medis jenis kelamin ada 3 orang, umur petugas rekam medis rata-rata 26 tahun, 28 tahun, dan 29 tahun. Pendidikan petugas Rekam Medis rawat jalan 3 orang perguruan tinggi. Masa kerja di Rekam Medis rawat jalan ada yang 1 bulan. 2 tahun dan 4 tahun. Dari hasil tabel di atas, rata-rata petugas Rekam Medis perempuan dan pendidikan kebanyakan perguruan tinggi (Sarjana).

Tabel 3. Kuesioner

\begin{tabular}{|c|c|c|c|}
\hline No & Pertanyaan & Ya & Tidak \\
\hline & h mengikuti pelatihan tentang & & 3 \\
\hline & Pelayanan Minimal (SPM)? & 3 & \\
\hline
\end{tabular}

Berdasarkan tabel 3 di atas, dari hasil pengamatan di atas, semua petugas di bagian pendaftaran Rawat Jalan lulusan Perguruan Tinggi. Tetapi, banyak yang tidak sesuai dengan jabatannya di pelayanan rekam medis. Hal ini berakibat pada waktu tunggu pasien.

\section{Sumber Daya Material}

Sumber daya material yang diteliti meliputi bahan, peralatan dan fasilitas. Hasil observasi terhadap sumber daya material tampak pada tabel dibawah.

Tabel 4. Hasil Observasi terhadap Sumber Daya Material Sarana prasarana di Instalasi Rekam Medis Rawat Jalan RSUD X Kabupaten Bandung Tahun 2021.

\begin{tabular}{llcc}
\hline No & Bahan & Ada & Tidak Ada \\
\hline 1. & Karcis di dekat loket penerimaan pasien & $\sqrt{ }$ & \\
\hline 2. & Buku register & $\sqrt{ }$ & \\
\hline 3. & Rekam Medis diberi map/ sampul & $\sqrt{ }$ & \\
\hline 4. & Kartu indek utama pasien & $\sqrt{ }$ & \\
\hline 5. & $\begin{array}{l}\text { Tanda petunjuk guna mempercepat pekerjaan } \\
\text { menyimpan dan menentukan rekam medis }\end{array}$ & & $\sqrt{ }$ \\
\hline 6. & $\begin{array}{l}\text { Kartu permintaan bagi peminjam rekam } \\
\text { medis }\end{array}$ & & \\
\hline
\end{tabular}




\begin{tabular}{lcc}
\hline 7. & $\begin{array}{l}\text { Tersedia kode warna map untuk mencegah } \\
\text { kekeliruan menyimpan dan memudahkan } \\
\text { mencari map yang salah }\end{array}$ & $\sqrt{ }$ \\
\hline 8. & $\begin{array}{l}\text { Terdapat tanda petunjuk keluar untuk } \\
\text { rekam medis yang tidak berada ditempat }\end{array}$ & $\sqrt{ }$ \\
\hline
\end{tabular}

Check List Sarana Prasarana di RSUD X Kabupaten Bandung

Tabel 5. Hasil Observasi terhadap Sumber Daya Material Peralatan di Instalasi Rekam Medis Rawat Jalan RSUD X Kabupaten Bandung Tahun 2021.

\begin{tabular}{llcc}
\hline No & \multicolumn{1}{c}{ Bahan } & Ada & Tidak Ada \\
\hline 1. & Alat tulis kantor (ATK) & $\sqrt{ }$ & \\
\hline 2. & Komputer untuk entry data & $\sqrt{ }$ & \\
\hline 3. & Buku pedoman pelaksanaan rekam medis & $\sqrt{ }$ \\
\hline 4. & Prosedur tetap (Protap) & $\sqrt{ }$ \\
\hline 5. & Ruang kerja lengkap dengan meja kerja & $\sqrt{ }$ \\
\hline 6. & Rak arsip dokumen berbentuk ras statis biasa & $\sqrt{ }$ \\
\hline 7. & Telepon & $\sqrt{ }$ \\
\hline
\end{tabular}

Check List Peralatan di RSUD X Kabupaten Bandung

Berdasarkan tabel 5 hasil observasi, terdapat tanda petunjuk kebutuhan akan peralatan tersebut pada umumnya hampir terpenuhi hanya buku pedoman pelaksanaan Rekam Medis yang tidak ada, akan tetapi tidak menutup kemungkinan bagi bagian Rekam Medis untuk mengajukan usulan peralatan lain yang berkaitan dengan kelancaran pelaksanaan kegiatan Rekam Medis.

Tabel 6. Hasil Observasi terhadap Sumber Daya Material Fasilitas di Instalasi Rekam Medis Rawat Jalan RSUD X Kabupaten Bandung Tahun 2021.

\begin{tabular}{|c|c|c|c|}
\hline No. & Bahan & Ada & Tidak Ada \\
\hline 1. & $\begin{array}{l}\text { Ruang pendaftaran pasien berdekatan dengan } \\
\text { ruang penyimpanan dokumen aktif }\end{array}$ & $\sqrt{ }$ & \\
\hline 2. & Ruang penyimpanan dokumen rekam medis & $\sqrt{ }$ & \\
\hline 3. & Lantai kedap air dan bebas banjir & $\sqrt{ }$ & \\
\hline 4. & Dinding permanen dan bersih & $\sqrt{ }$ & \\
\hline 5. & Cukup ventilasi & & $\sqrt{ }$ \\
\hline 6. & $\begin{array}{l}\text { Jarak antara dua rak untuk lalu lintas minimal } \\
90 \mathrm{~cm}\end{array}$ & $\sqrt{ }$ & \\
\hline 7. & $\begin{array}{l}\text { Ruang penyimpanan rekam medis aktif } \\
\text { cukup luas untuk semua data }\end{array}$ & $\sqrt{ }$ & \\
\hline 8. & $\begin{array}{l}\text { Ruang cukup aman untuk melindungi dari } \\
\text { kehilangan, kerusakan, serta mencegah } \\
\text { digunakan oleh yang tidak berkepentingan }\end{array}$ & $\sqrt{ }$ & \\
\hline 9. & Penerangan tempat penyimpanan baik & & $\sqrt{ }$ \\
\hline 10. & Suhu ruangan baik & $\sqrt{ }$ & \\
\hline
\end{tabular}

Berdasarkan pada table 6 hasil observasi, ruang kerja ada dengan meja kerja dan ada rak arsip dokumen berbentuk rak terbuka biasa. Fasilitas yang dimiliki yaitu ruang pendaftaran pasien berdekatan dengan ruang penyimpanan dokumen aktif, ruang penyimpanan dokumen rekam medis, dinding permanen dan bersih, jarak antara dua rak untuk lalu lintas minimal $90 \mathrm{~cm}$, ruang penyimpanan rekam medis aktif cukup luas untuk semua data, ruang cukup aman untuk melindungi dari kehilangan, kerusakan, serta mencegah digunakan oleh yang tidak berkepentingan, suhu ruangan baik. Masalah yang 
didapatkan adalah penerangan tempat penyimpanan kurang baik serta tidak cukup ventilasi kurang baik untuk ruang penyimpanan.

\section{B. Pembahasan}

Berlandaskan hasil pengukuran dan observasi yang dilakukan peneliti menurut (Depkes, 2007) disebutkan bahwa penyediaan dokumen rekam medis itu adalah dimulai dari saat pasien mendaftar sampai dokumen rekam medis disediakan atau ditemukan oleh petugas dengan standar pelayanan minimalnya adalah 10 menit untuk pelayanan rawat jalan dan 15 menit untuk pelayanan rawat inap.

Berdasarkan yang peneliti temukan dilapangan bahwa rata-rata waktu tunggu yang dibutuhkan untuk pasien baru di RSUD X Kabupaten Bandung adalah 4 menit 11 detik dan untuk pasien lama adalah 6 menit 35 detik. Umur petugas pendaftaran rawat jalan ada yang 26 tahun, 28 tahun, dan 29 tahun. Tingkat pendidikan petugas pendaftaran rawat jalan semua lulusan Perguruan Tinggi (Sarjana). Masa kerja petugas pendaftaran rawat jalan diketahui ada yang masih 1 bulan, 2 tahun, dan 4 tahun. Semua petugas pendaftaran rawat jalan belum pernah mengikuti pelatihan tentang rekam medis. Petugas pendaftaran rawat jalan mengatakan adanya Standar Pelayanan Minimal (SPM).

Pelatihan tentang rekam medis sangat penting untuk petugas. Karena, di dalam pelatihan dapat memberikan edukasi untuk petugas pendaftaran rawat jalan. Tingkat pendidikan juga sangat berpengaruh dalam bekerja. Petugas pendaftaran rawat jalan semua lulusan Perguruan Tinggi (Sarjana). Tetapi, banyak yang tidak sesuai dengan jabatannya. Dengan demikian kebutuhan akan kualitas tenaga di instalasi rekam medis rawat jalan belum terpenuhi.

\section{Sumber Daya Manusia}

Sumber Daya Manusia (SDM) merupakan sumber daya manusia yang sangat berperan penting bagi pelayan rumah sakit (Kiranayanti \& Erawati, 2016). Penanganan SDM penting karena mutu pelayanan rumah sakit sangat tergantung dari perilaku SDM dan kemajuan ilmu dan teknologi memerlukan tenaga yang profesional dan spesialis. Mutu pelayanan rumah sakit itu termasuk pelayanan pendaftaran rawat jalan (Darlis, 2012). Berdasarkan hasil penelitian dengan menggunakan alat bantu kuesioner, petugas pendaftaran rawat jalan ada 3 orang dengan jenis kelamin perempuan. Rata-rata petugas pendaftaran rawat jalan memiliki jabatan yang tidak sesuai. Tetapi, SPM sudah sesuai dengan standar teknis pemenuhan mutu pelayanan rumah sakit.

\section{Sumber Daya Material}

Penyelenggaraan kegiatan rekam medis perlu didukung sumber daya material yang meliputi bahan, peralatan, dan fasilitas. Bahan adalah formulir dan kartu atau sejenisnya yang telah dicetak untuk menunjang pelaksanaan rekam medis. Peralatan dan fasilitas adalah segala sesuatu yang memudahkan pelaksanaan dan pengelolaan rekam medis (Suraja, 2019). Alat penyimpanan yang baik, pemeliharaan ruangan yang bersih, penerangan ruangan yang baik serta perhatian terhadap faktor keselamatan sangat membantu meningkatkan produktivitas petugas (Simanjuntak, 2016). Alat penyimpanan berkas rekam medis menggunakan rak buka tutup (roll o'pack). Fasilitas yang dimiliki Rumah Sakit X Kabupaten Bandung yaitu ruang pendaftaran pasien berdekatan dengan ruang penyimpanan rekam medis aktif dan ruang pengelola data dekat dengan ruang penerimaan pasien. Ruang penyimpanan rekam medis, yaitu kondisi lantai kedap air dan bebas banjir, dinding permanen dan bersih sudah terpenuhi. Tetapi, kurang ventilasi yang mengakibatkan suhu ruangan kurang menyegarkan untuk petugas. Hal ini menghambat pencarian berkas rekam medis dan berakibat pada waktu tunggu pasien. 


\section{KESIMPULAN}

Proses pendaftaran rawat jalan dalam kegiatan pelayanan rekam medis yang meliputi pendaftaran, penerimaan pasien, pendataan, penyimpanan dan pengembalian dokumen sangat berpengaruh terhadap waktu tunggu pelayanan rekam medis. Sumber Daya Manusia yaitu data riwayat hidup petugas dan Sumber Daya Material rekam medis di RSUD $\mathrm{X}$ Kabupaten Bandung yang meliputi bahan dan fasilitas juga merupakan faktor yang mempengaruhi waktu tunggu pelayanan rekam medis.

Berdasarkan hasil tinjauan bahwa waktu tunggu pelayanan rekam medis di pendaftaran rawat jalan rumah sakit tersebut sudah dikategorikan singkat sehingga tidak ada permasalahan yang menonjol hanya saja pada faktor petugas yang tidak pernah mengikuti pelatihan rekam medis, tetapi tidak menutup kemungkinan karena faktor tersebut dapat menghambat waktu tunggu pelayanan rekam medis. Rumah sakit tersebut sudah memenuhi standar pelayanan rekam medis di pendaftaran rawat jalan dengan minimal 10 menit. Fasilitas tempat penyimpanan yang memiliki penerangan dan ventilasi yang kurang baik dapat menghambat dalam pencarian berkas rekam medis. Meskipun faktor-faktor tersebut tidak terlalu menjadi permasalahan yang dapat menghambat waktu pelayanan, peneliti menyarankan sebaiknya jumlah penerangan pada suatu ruangan terbagi menjadi 2 yaitu penerangan alami dan buatan seperti penerangan alami ruang penyimpanan sebaiknya dioptimalkan ke dalam bangunan atau ruang kerja sehingga akan mendapatkan banyak manfaat dari adanya penerangan ini. Guna penerangan buatan diterapkan dengan memberikan lampu atau efek cahaya yang berdifusi terinfeksi terlebih dahulu sebelum akhirnya menyinari area ruangan yang ada disekitarnya dan menambah ventilasi yang cukup agar waktu tunggu pelayanan rekam medis bisa berjalan dengan maksimal dan menjadi utilitas pasien di masa yang akan datang.

\section{BIBLIOGRAFI}

DARLIS, N. I. M. (2012). Tinjauan Waktu Tunggu Pelayanan Rekam Medis di Pendaftaran Rawat Jalan Rumah Sakit Umum Daerah dr. H. Yuliddin Jalan Tapaktuan Kabupaten Aceh Selatan Tahun 2012. Universitas Teuku Umar Meulaboh.

Depkes. (2007). Standar Pelayanan Minimal Rumah Sakit. Jakarta: Departemen Kesehatan RI.

Febriyanti, D. H., Kurniadi, A., Kom, M., \& Nuswantoro, A. (2013). Deskripsi Faktorfaktor yang Mempengaruhi Waktu Tunggu Pendaftaran di TPPRJ RSUD Tugurejo Semarang Tahun 2013. Skripsi. Fakultas Kesehatan. Universitas Dian Nuswantoro. Semarang.

Fuanasari, A. D., Suparwati, A., \& Wigati, P. A. (2014). Analisis alur pelayanan dan antrian di loket pendaftaran pasien rawat jalan. Jurnal Kesehatan Masyarakat (Undip), 2(1), $15-21$.

Hidayat, W. (2017). Strategi Rumah Sakit Umum Daerah Panglima Sebaya Tanah Grogot dalam Meningkatkan Kualitas Pelayanan Kesehatan di Kabupaten Paser.

Ismawati, I., Yulianti, N. A., \& Sari, I. (2021). Faktor-Faktor Penyebab Keterlambatan Distribusi Rekam Medis Rawat Jalan di Rumah Sakit TK II Dustira Cimahi. Cerdika: Jurnal Ilmiah Indonesia, 1(7), 8015-8020.

Karuniawati, H., Hapsari, I. G., Arum, M., Aurora, A. T., \& Wahyono, N. A. (2016). Evaluasi pelaksanan standar pelayanan minimal (SPM) farmasi kategori lama waktu tunggu pelayanan resep pasien rawat jalan di RSUD Kota Salatiga. Kartika: Jurnal Ilmiah Farmasi, 4(1), 20-25.

Kiranayanti, I. A. E., \& Erawati, N. M. A. (2016). Pengaruh Sumber Daya Manusia, Sistem

Tinjauan Faktor-Faktor Yang Mempengaruhi Waktu Tunggu Pelayanan Rekam Medis di Pendaftaran Rawat Jalan Rsud X Kabupaten Bandung 
Pengendalian Intern, Pemahaman Basis Akrual Terhadap Kualitas Laporan Keuangan Daerah. E-Jurnal Akuntansi Universitas Udayana, 16(2), 1290-1318.

No, U. (44 C.E.). Tahun 2009 Rumah Sakit. Indonesia.

Permenkes. (2008). Peraturan Menteri Kesehatan No.269/MENKES/PER/III/2008.

RI, D. (2008). Keputusan Menteri Kesehatan Republik Indoneia Nomor. 129 Tahun 2009 Tentang Standar Pelayanan Minimal Rumah Sakit. Jakarta: Kemenkes RI.

Simanjuntak, M. (2016). Tinjauan faktor-faktor yang mempengaruhi waktu tunggu Pelayanan Rekam Medis Di Pendaftaran Rawat Jalan Di RSUD. Dr. RM Djoelham Binjai Tahun 2015. Jurnal Ilmiah Perekam Dan Informasi Kesehatan Imelda (JIPIKI), 1(1), 22-29.

Soendari, T. (2012). Metode Penelitian Deskriptif. Bandung, UPI. Stuss, Magdalena \& Herdan, Agnieszka, 17.

Suraja, Y. (2019). Pengelolaan Rekam Medis Pada Fasilitas Pelayanan Kesehatan. Jurnal Administrasi Dan Kesehatan, 4(1), 62-71.

YanMed, D., \& Depkes, R. I. (1997). Pedoman Pengelolaan Rekam Medis Rumah Sakit di Indonesia. DepKes RI, Jakarta.

(c) 2021 by the authors. Submitted for possible open access publication under the terms and conditions of the Creative Commons Attribution (CC BY SA) license (https://creativecommons.org/licenses/by-sa/4.0/). 